\title{
THE ROLE OF DISPOSITIONAL EMPLOYABILITY IN DETERMINING INDIVIDUAL DIFFERENCES IN CAREER SUCCESS
}

Darja MASLIĆ SERŠIĆ, Jasmina TOMAS

Faculty of Humanities and Social Sciences, Zagreb

UDK: $331.108 .4(497.5)$

Izvorni znanstveni rad

Primljeno: 5. 3. 2014.

The purpose of the study was twofold: (1) to reassess the model of Dispositional Employability (DE) proposed by Fugate and Kinicki (2008) in the Croatian economic context, and (2) to validate a new measure of DE through testing its discriminant and incremental validity in relation to core self-evaluations (CSE). A Croatian version of the DE scale was constructed based on a qualitative study and applied to a heterogeneous sample of 966 Croatian employees. In addition, we measured CSE, as well as four criterion variables: subjective career success, general job satisfaction, relative income and perceived employability. A CFA was performed to test whether the measures of DE and CSE were assessing two distinct dimensions. The results are in line with the hypothesis of the discriminant validity of the constructs. Moreover, results of hierarchical regression analyses showed that DE accounted for additional variance of subjective career success, job satisfaction and perceived employability above and beyond control variables and CSE. These findings indicate which psycho-social characteristics make people employable in different economic contexts and provide empirical support for the validity of a new DE scale. In the end, we discuss limitations, contributions and suggestions for future research.

Keywords: dispositional employability, core self-evaluations, career success, discriminant validity, incremental validity

$\triangle \quad$ Darja Maslić Seršić, Department of Psychology, Faculty of Humanities and Social Sciences, University of Zagreb, Ivana Lučića 3, 10000 Zagreb, Croatia. 
Current interest in employability as a characteristic of a labour force or a working individual has been driven by the increasing unemployment rates and intensified job insecurity experienced in most of the European countries in the last two decades (see De Cuyper, Bernhard-Oettel, Berntson, De Witte, \& Alarco, 2008; Fugate, Kinicki, \& Ashforth, 2004; Weinert, 2001). Although most authors agree that employability refers to the employees' chances of finding alternative employment, they use various indicators of this concept. In psychology, three types of measures have arisen as dominant: (1) objective indicators relating to human capital, such as age, education, position and organizational tenure, which predict (re)employment success (e.g., Forrier \& Sels, 2003; Maslić Seršić \& Šavor, 2012; Šverko, Galić, Maslić Seršić, \& Galešić, 2008; Worth, 2002); (2) employees' self-rated abilities of obtaining alternative jobs in the existing organization or open labour market, known as perceived employability (Berntson, Sverke, \& Marklund, 2006; Berntson \& Marklund 2007; De Cuyper et al., 2008; Silla, De Cuyper, Gracia, Peiro, \& De Witte (2009); (3) individual differences in work-related competences, values, attitudes and behaviour that predispose individuals for employability and career success in general (Fugate \& Kinicki, 2008; Fugate et al., 2004; Van Dam, 2004; Van Der Heijde \& Van Der Heijden, 2006).

Regardless of the nature and content of individual differences, the last approach encompasses domain-independent characteristics of an individual that predispose him or her for career success and well-being in various working settings. In this regard, current literature underlines the relevance of employability for individual and organizational efficiency, distinguishing two different perspectives. The first of them is that developed by Fugate et al. (2004), who focus mainly on individual career outcomes, defining employability as "a form of work-specific active adaptability that enables workers to identify and realize career opportunities" (p. 16). In line with this approach, Fugate and Kinicki (2008) defined the model of dispositional employability (DE), which is the focus of the current study. On the other hand, Van Dam (2004) focuses on organizational efficacy, discussing individual employability orientation as a set of competences that enable the employee to succeed in a flexible modern organization.

Although focusing on somewhat different employee characteristics, the competence-based (Van Dam, 2004; Van der Heijde \& Van der Heijden, 2006) and dispositional (Fugate \& Kinicki, 2008; Fugate et al., 2004) approaches to employability 
DRUŠ. ISTRAŽ. ZAGREB GOD. 23 (2014), BR. 4 STR. 593-613

MASLIĆ SERŠIĆ, D., TOMAS, J.: THE ROLE OF.. are complementary, rather than contradictory to each other. Both stress the necessity for personal flexibility and self-initiated proactive behaviour as characteristics which are necessary for successful coping with fast-changing job requirements in an era of boundaryless careers (Briscoe, Hall, \& Demuth, 2006; Hall, 2004; Van der Heijde, 2014) and flexible organizations (Valverde, Tregaskis, \& Brewster, 2000). In this regard, the ever-changing work environment can be specified as a weak situation (Mischel, 1977) in which the domain-independent, generic concept of employability becomes relevant for both researchers and practitioners.

Van der Heijde and Van der Heijden (2006) address five generic competences as key for employability: occupational expertise, defined as professional knowledge and skills, including related meta-cognitive abilities; anticipation and optimization, defined through proactive and planned professional development; personal flexibility, as the capacity to anticipate and adapt to changes in work settings; corporate sense, as a competence of meeting and internalizing organizational goals; and finally balance, as an ability to make an efficient compromise between personal and organizational interests.

The dispositional approach defines employability through a set of individual characteristics that determine the current and future position in the labour market (Sanders \& De Grip, 2004). In accordance with this approach, Fugate and Kinicki (2008) indicated five key characteristics as the individual predispositions for employability: openness to changes at work, work and career resilience, work and career proactivity, career motivation and work identity. These characteristics are defined by the second-order factor of $\mathrm{DE}$, which predisposes individuals for successful coping with an uncertain and protean working context (Fugate \& Kinicki, 2008). Along with human-capital variables, individual dispositions of employability are conceived of as predictors of positive work-related outcomes, such as perceived employability, employee well-being and career success. The dispositional approach to the construct of employability represents a useful alternative to the line of traditional research and practice that posits a reactive employee orientation (employees responding after the situational changes occur or are known). In contrast, the current approach acknowledges the importance of employee initiative and proactivity in understanding work behaviour and work-related outcomes. Consistent with this trend, DE is conceptualized as encompassing both reactive and proactive personal characteristics. This means that, in addition to the ability to adapt reactively to known demands, employable individuals tend 
DRUŠ. ISTRAŽ. ZAGREB GOD. 23 (2014), BR. 4, STR. 593-613

MASLIĆ SERŠIĆ, D. TOMAS, J.

THE ROLE OF. to have a perpetual readiness for change (Fugate \& Kinicki, 2008). As Sanders and De Grip (2004) stated, employability implies "the capacity and willingness to be and to remain attractive in the labour market, by anticipating changes in tasks and work environment and reacting to these changes in a proactive way" (p. 76). In other words, employable individuals will identify, proactively create and realize opportunities both within and between organizations (Fugate et al., 2004).

With regard to the above, the concept of DE is in the main focus of this paper. As Croatian society has undergone a radical transition from a society of state socialism, characterized by low work mobility and high job security, to a market economy, its labour force has met many new challenges (Maslić Seršić, Šverko, \& Galić, 2005). The adjusting process has been especially difficult for employees in the business sector: The majority of Croatian companies have undergone a process of privatization and restructuring followed by downsizing and massive lay-offs (Dujšin, 1999). Consequently, many working people have experienced their occupational expertise as outdated, or at least insufficient for gaining employment. These circumstances have been reflected in a high unemployment rate (22\% and 20\% in 2003 and 2013, respectively), with one of the lowest employment rates in Europe (barely 50\%), which has characterized the Croatian economy for more than a decade (DZS, 2013; Eurostat, 2012). In such an environment, keeping a job or finding a new one has become a demanding challenge for the greater part of the working population. Since studies on DE have been conducted in different economic settings characterized by lower unemployment rates and higher mobility, we found it relevant to explore individual characteristics that Croatian employees see as crucial for gaining and maintaining a job in a formal organization (Forrier \& Sels, 2003; Fugate et al., 2004; Hillage \& Pollard, 1998).

Therefore, the first aim of our study was to reassess the model of DE proposed by Fugate and Kinicki (2008) in the context of Croatian society and consequently to develop a measure of DE adapted to the economy and culture of Croatia. In other words, we aimed to evaluate the concept of DE in a different context through investigating individual characteristics that predispose an individual for gaining and maintaining employment. The second aim of our study was to test the construct validity of the developed measure of DE through investigating its discriminant and incremental validity in predicting career success and perceived employability in relation to the conceptually similar and well-known concept of core 
DRUŠ. ISTRAŽ. ZAGREB GOD. 23 (2014), BR. 4 STR. 593-613

MASLIĆ SERŠIĆ, D., TOMAS, J.: THE ROLE OF. self-evaluations (CSE) (Erez \& Judge, 2001; Judge, Erez, Bono, \& Thoresen, 2003). According to Judge, Locke, and Durham (1997), CSE is a broad, higher-order individual characteristic composed of personality traits which predict career success and employee well-being. Similar to the construct of DE, CSE can be seen as an individual's work-related coping resource of adaptive strategies for coping with the challenging demands of a modern work context (Lazarus \& Folkman, 1984; Taylor \& Stanton, 2007). In this regard, the concept of CSE has been studied in numerous research projects. Judge et al. (2003) developed the Core Self-Evaluations Scale (CSES) as a 12-item measure of the concept, whose construct validity has been confirmed in many studies (e.g., Erez \& Judge, 2001; Judge, Locke, Durham, \& Kluger, 1998). The validity of the measure has been supported in a Croatian context, as well (Maslić Seršić \& Šavor, 2012). As a brief composite measure of relevant traits - self-esteem, generalized self-efficacy, neuroticism and locus of control - the higher-order dimension of CSE is correlated to job satisfaction, work performance, career success, general well-being and successful coping with setbacks (e.g., Bono \& Judge, 2003; Judge, Bono, Erez, \& Locke, 2005; Judge \& Hurst, 2008; Judge \& Kammeyer-Mueller, 2011; Rode, Judge, \& Sun, 2012). Furthermore, in the literature on unemployment, the CSES is used as a measure of individual coping resources that predicts successful coping with job loss (for review, see Chang, Ferris, Johnson, Rosen, \& Tan, 2012; Judge \& Kammeyer-Mueller, 2011). In a Croatian context, CSE predicted the active problem-focused strategy of job search after job loss, and correlated negatively with the maladaptive emotional coping strategy of distancing in the same situation (Maslić Seršić \& Šavor, 2012). In the same study, it was shown that the strategy of job search predicted re-employment success 6 months later. Considering this established tradition of using the CSES in predicting individual effectiveness in coping with the numerous demands of a modern work environment, we have found this measure convenient for testing discriminant and incremental validity of the Croatian version of the measure of DE.

\section{METHOD}

\section{Sample and procedure}

The data was collected with a convenience sampling method among 966 Croatian employees with various demographics and work-related characteristics. As can be observed from Table 1, our sample comprised more women, young and high- 
DRUŠ. ISTRAŽ. ZAGREB GOD. 23 (2014), BR. 4, STR. 593-613

MASLIĆ SERŠIĆ, D.

TOMAS, J.

THE ROLE OF..

Э TABLE

Sample characteristics

\begin{tabular}{|c|c|c|}
\hline Variable & & $\mathrm{N}(\%)$ \\
\hline Gender & $\begin{array}{l}\text { Male } \\
\text { Female }\end{array}$ & $\begin{array}{l}351(37.5) \\
585(62.5)\end{array}$ \\
\hline Age & $\begin{array}{l}18-25 \\
26-35 \\
36-45 \\
46-55 \\
56-65\end{array}$ & $\begin{array}{r}90(9.5) \\
376(39.3) \\
241(25.2) \\
183(19.1) \\
66(6.9)\end{array}$ \\
\hline Education level & $\begin{array}{l}\text { Primary school } \\
\text { High school up to } 3 \text { years } \\
\text { High school up to } 4 \text { years } \\
\text { University, art academy } \\
\text { or polytechnic } \\
\text { Postgraduate studies }\end{array}$ & $\begin{array}{r}14(1.5) \\
97(10.1) \\
320(33.4) \\
469(48.9) \\
59(6.2)\end{array}$ \\
\hline Monthly income & $\begin{array}{l}<3,500 \mathrm{kn} \\
3,500-5,500 \mathrm{kn} \\
5,501-7,000 \mathrm{kn} \\
7,001-10,000 \mathrm{kn} \\
>10,000 \mathrm{kn}\end{array}$ & $\begin{array}{l}118(12.4) \\
332(34.8) \\
263(27.6) \\
137(14.4) \\
104(10.9)\end{array}$ \\
\hline Managerial position & $\begin{array}{l}\text { non-managerial position } \\
\text { lower-level managerial position } \\
\text { middle-level managerial position } \\
\text { high-level managerial position }\end{array}$ & $\begin{array}{r}543(57.0) \\
202(21.2) \\
161(16.9) \\
47(4.9)\end{array}$ \\
\hline Organization tenure & $\begin{array}{l}\text { up to } 3 \text { years } \\
3-5 \\
6-10 \\
11-15 \\
>15\end{array}$ & $\begin{array}{l}268(27.9) \\
212(22.1) \\
187(19.5) \\
102(10.7) \\
191(19.6)\end{array}$ \\
\hline
\end{tabular}

\section{Measures}

ly educated respondents. In addition, more employees had no managerial position and had worked up to 5 years in their current organization. Respondents were recruited individually and via the human-resource departments of several organizations in the industry and retail sector. The surveys were collected in paper-and-pencil format $(62.42 \%)$ and on-line $(37.58 \%)$, accompanied by instructions stressing confidentiality and the voluntary nature of participation. Furthermore, the importance of the study for all parties involved was underlined in order to increase the response rates.

\section{Dispositional employability}

To measure DE, we applied a dispositional measure of employability, based on Fugate and Kinicki's (2008) model. The scale was developed for the purpose of this study. In a pilot-study, five dimensions of the Fugate and Kinicki's (2008) 
DRUŠ. ISTRAŽ. ZAGREB GOD. 23 (2014), BR. 4 STR. 593-613

MASLIĆ SERŠIĆ, D., TOMAS, J.: THE ROLE OF.. model, which are considered critical in defining DE, were reassessed in a Croatian context. Specifically, we collected qualitative data on individual characteristics, which predispose a person for employability, through 4 focus groups consisting of 5-7 participants of various demographic and work characteristics. The results of CFA confirmed a hypothesized second-order structure of DE consisting of 4 first-order factors $\left(\chi^{2}(185)=829.11, \mathrm{p}<0.01, \mathrm{SRMR}=0.05, \mathrm{RMSEA}=0.063\right.$ [C.I. $=0.059-0.067]$, CFI $=0.92)$ : work self-efficacy $(8$ items, e.g. "I have confidence in my work abilities", $\alpha=0.86$ ), work proactivity ( 5 items, e.g. "If I have a good idea at work, I try to find a way to implement it", $\alpha=0.82$ ), work engagement (5 items, e.g. "I put extra effort into my work even if I am not additionally rewarded", $\alpha=0.80$ ) and social capital ( 3 items, e.g. "I easily make new acquaintances who can help me in my career", $\alpha=0.80$ ). Respondents had to indicate the degree to which a certain item concerned them on a scale ranging from 1 (doesn't concern me at all) to 5 (completely concerns me).

\section{Core self-evaluations}

We measured CSE with a 12-item scale developed by Judge et al. (2003). This scale is intended to measure respondents' basic self-evaluations through assessing the levels of their general self-efficacy, self-esteem, neuroticism and locus of control. The sample item of this measure is: "I am confident I get the success I deserve in life". Answers are indicated on a 5-point scale ranging from 1 (strongly disagree) to 5 (strongly agree). Reliability of this scale equalled $\alpha=0.83$. Total score is an average of all items forming this scale. Higher scores indicate higher levels of respondents' core self-evaluations.

\section{Subjective career success}

Subjective career success was measured with a 5-item scale developed by Greenhaus, Parasuraman, and Wormley (1990). Respondents indicated the degree to which they are satisfied with certain aspects of their careers on a 5-point scale ranging from 1 (completely satisfied) to 5 (completely dissatisfied). The sample item is: "I am satisfied with the progress I have made towards meeting my overall career goals". Cronbach's alpha for this measure was 0.85 . Total score for each respondent was calculated as an average of items, with higher score indicating higher level of subjective career success.

\section{Job satisfaction}

Job satisfaction was measured with a 4-item scale (Maslić Seršić \& Šverko, 2000; Maslić Seršić et al., 2005). This scale measures respondents' global job satisfaction. The sample item is: 
DRUŠ. ISTRAŽ. ZAGREB GOD. 23 (2014), BR. 4, STR. 593-613

MASLIĆ SERŠIĆ, D., TOMAS, J.

THE ROLE OF.
"Compared to other employees, how satisfied are you with your current job and situation at work?". Answers on this item range from 1 (nobody else is as dissatisfied as I am) to 5 (nobody else is as satisfied as I am). Cronbach's alpha for this measure was 0.77 . Total score is calculated by averaging scores on all items. Higher scores indicate higher levels of employees' job satisfaction.

\section{Perceived income}

Relative income was measured with one item: "Compared to others, your monthly income is (1) much lower, (2) lower, (3) equal, (4) higher or (5) much higher."

\section{Perceived employability}

To measure perceived employability we used the 4-item scale developed by De Witte (2000). Respondents indicated the degree to which they perceived they could obtain new employment on a 5-point Likert-type scale ranging from 1 (strongly disagree) to 5 (strongly agree). The sample item is: "I will easily find another job if I lose this job". Reliability for this scale was $\alpha=0.90$. Total score was calculated as an average of items, with higher scores indicating higher levels of perceived employability.

\section{Control variables}

In order to exclude alternative explanations of our results, several demographics and work-related variables were included in the study. Specifically, demographics included: gender (male, female), age (measured as a categorical variable: 18 $25,26-35,36-45,46-55,56-65$ ) and education (assessed as the highest level of education completed: primary school, high school up to 3 years, high school up to 4 years, university, art academy or polytechnic, and postgraduate studies). Work-related variables included: monthly income (measured as a categorical variable: less than $3,500 \mathrm{kn}, 3,500-5,500 \mathrm{kn}$, 5,501-7,000 kn, 7,001-10,000 kn and more than 10,000 kn), organizational tenure (measured in years) and managerial position (measured as a categorical variable: non-managerial position, lower-level managerial position, middle-level managerial position and high-level managerial position).

\section{DATA ANALYSES}

In order to answer our research questions, two sets of analysis were conducted. First, a confirmatory factor analysis (CFA) was performed with the IBM SPSS AMOS software package, Version 21 (Arbuckle, 2012), to test whether the measures of DE and CSE were assessing two distinct dimensions. We used the covariance matrix with listwise deletion $(\mathrm{N}=880)$ as the 
DRUŠ. ISTRAŽ. ZAGREB GOD. 23 (2014), BR. 4 STR. 593-613

MASLIĆ SERŠIĆ, D., TOMAS, J.: THE ROLE OF.. input for the analysis and maximum likelihood estimation of parameters. The number of indicators per latent variable (work engagement, self-efficacy, proactivity and CSE) was reduced in order to maintain the robustness of the analysis and facilitate the model fit. As there were only three items measuring social capital, they were not parcelled. In this respect, we followed the procedure described by Landis, Beal, and Tesluk (2000). Specifically, we subjected all items on a particular (sub)scale to an exploratory factor analysis in which a single-factor solution was specified. Based on the results of this analysis, we paired the items with the highest and lowest factor loadings in one parcel. Then we proceeded with pairing the items with the remaining highest and lowest factor loadings into the second composite and continued until all items were assigned. Thus, we formed empirically balanced indicators of constructs. A combination of absolute, parsimonious and comparative fit indices was used to evaluate the fit of the tested models: chi-square, SRMR, RMSEA (with 90\% confidence interval) and CFI. To assess the model fit, we used the following criteria: a non-significant chi-square test, SRMR and RMSEA values no higher than 0.08 (with the upper boundary of the RMSEA confidence interval no higher than 0.10 ), and CFI values of 0.90 or higher (Bentler, 1990; Bentler \& Bonnett, 1980; $\mathrm{Hu} \&$ Bentler, 1999). In addition, we examined the local fit indicators, such as magnitude and statistical significance of factor loadings. Finally, in order to test the discriminant validity of the two measures, we compared the hypothesized two-factor model (DE and CSE as correlated factors: Model 1) with an alternative one-factor model in which all indicators were specified to load on a single factor (Model 2). Comparison of these two alternative nested models was conducted with the chi-square difference test.

The second procedure investigated the incremental validity of the dispositional measure of employability. Specifically, to test whether DE accounts for a significant amount of variance above CSE, we conducted a set of hierarchical multiple regression analyses separately for each outcome. In step 1 , we introduced demographic and work-related control variables. CSE and DE were introduced in steps 2 and 3, respectively. Therefore, incremental validity for the dispositional measure of employability is shown if it explains a significant criterion variance beyond that explained by CSE.

\section{RESULTS}

Descriptives, reliabilities (Cronbach's alpha coefficients) and correlations between the study variables are presented in Table 2. 


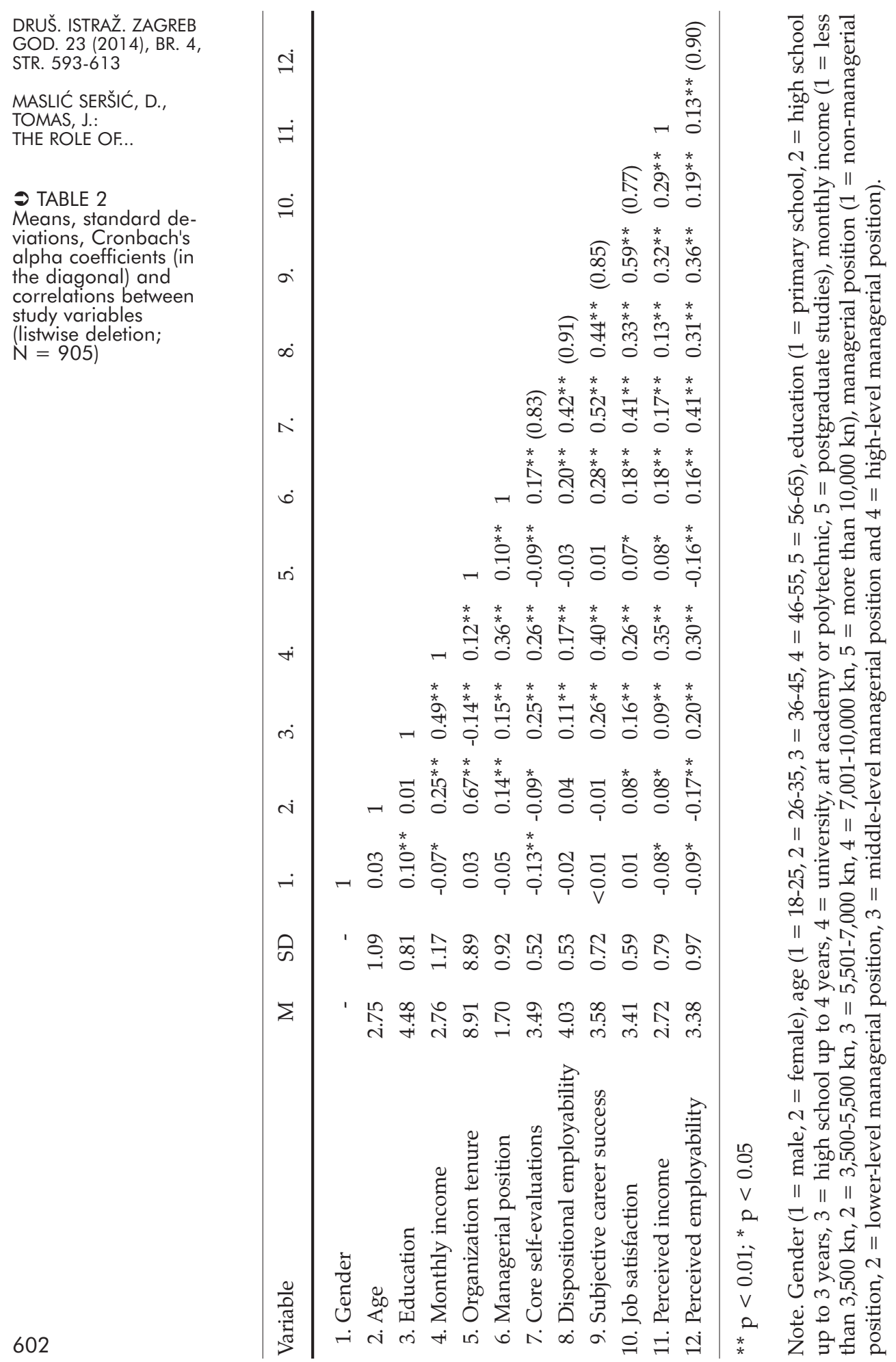




\section{Confirmatory factor analysis}

Results of overall fit indices are presented in Table 3.

\begin{tabular}{lrrrrrrr}
\hline Model & $\chi^{2}$ & $\operatorname{df}\left(\chi^{2}\right)$ & $\Delta \chi^{2}(\Delta \mathrm{df})$ & $(\Delta \mathrm{df})$ & SRMR & RMSEA (C.I.) & CFI \\
\hline Model 1 & $263.06^{* * *}$ & 60 & - & - & 0.041 & $0.062(0.054-0.070)$ & 0.97 \\
Model 2 & $2030.91^{* * *}$ & 65 & $1767.85^{* * *}$ & 5 & 0.111 & $0.185(0.179-0.192)$ & 0.67 \\
\hline
\end{tabular}

*** $\mathrm{p}<0.001$

(1) TABLE 3

Model fit statistics

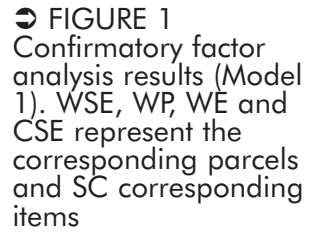

First, we made a comparison between a hypothesized two-factor model (Model 1) and a constrained one-factor model (Model 2). According to the chi-square difference test, Model 1 shows a significantly better fit to the data than does Model 2. Furthermore, overall fit statistics indicate a very good fit of the proposed two-factor model: with the exception of a statistically significant chi-square test, which is a common result in studies with large samples such as ours, other fit indices are in an acceptable range. Model 1 is presented in Figure 1 . As can be seen, all standardized factor loadings are statistically significant and higher than 0.70 , supporting the scale validity of the measures of DE and CSE. In addition, the correlation between the two factors is 0.50. According to Brown (2006), factor intercorrelations below 0.85 imply a good discriminant validity of the measures. Overall, these results provide empirical data to support the claim that the indicators of the presented constructs load onto separate factors in the expected manner.

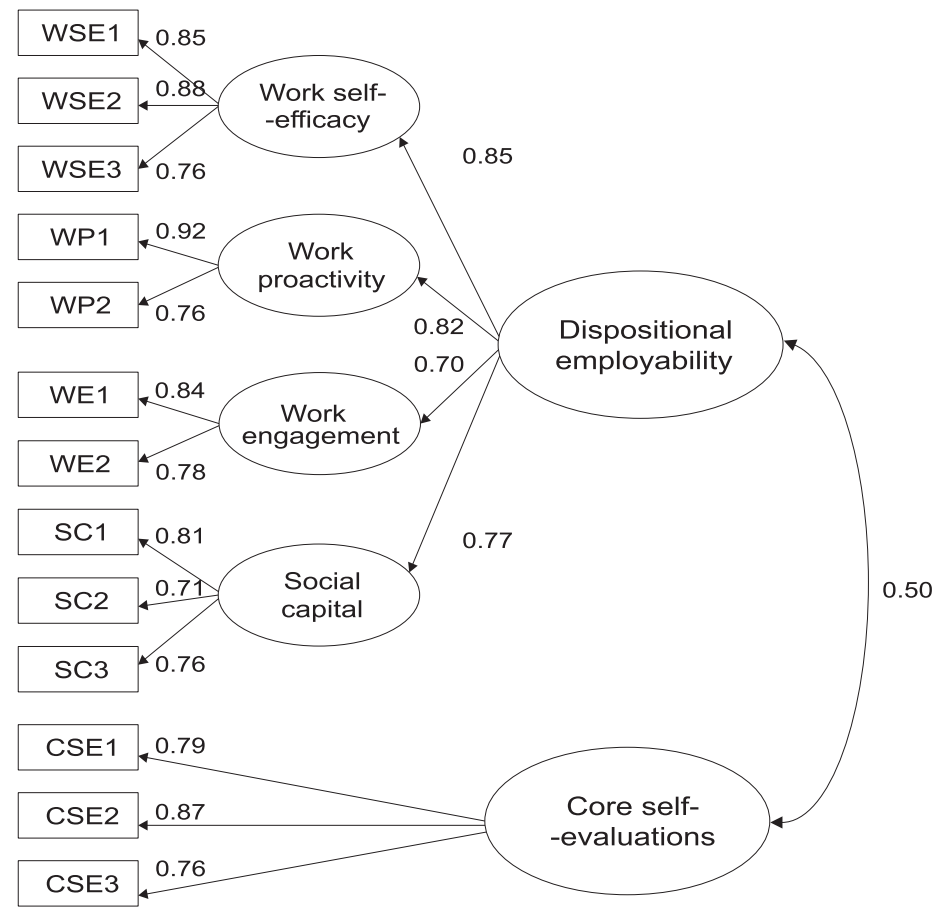




\section{Hierarchical regression analyses}

Following the CFA, we conducted four hierarchical regression analyses with subjective career success, job satisfaction, relative income and perceived employability as outcomes. The results are presented in Table 4.

จ TABLE 4

Hierarchical regression analyses with

subjective career

success, job

satisfaction, perceived

income and perceived

employability as

outcomes (listwise deletion)

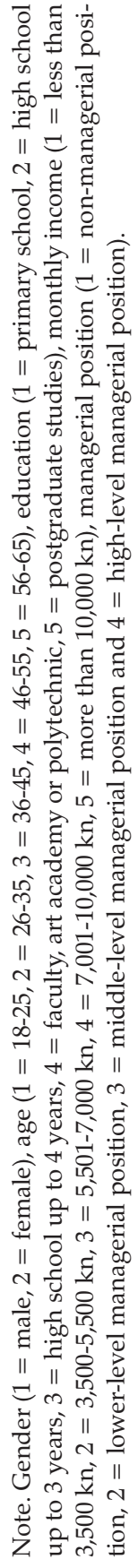


DRUŠ. ISTRAŽ. ZAGREB GOD. 23 (2014), BR. 4 STR. 593-613

MASLIĆ SERŠIĆ, D. TOMAS, J.: THE ROLE OF..
With regard to subjective career success, demographics and work-related variables accounted for $20 \%(\mathrm{p}<0.01)$ of the explained variance, with age, education, monthly income and managerial position as significant predictors. Older respondents and respondents with higher education level, monthly income and managerial position perceived their careers as more successful. As hypothesized, CSE contributed significantly to the prediction of the first outcome, accounting for $16 \%$ of the variance $(\beta=0.43, p<0.01)$. Finally, when introduced in the third step, DE added five percent of the explained variance of subjective career success beyond CSE and the control variables $(\beta=0.25, p<0.01)$. Respondents with higher levels of both CSE and DE experienced more career success. Thereby, DE accounted for the extra variance when controlling for demographics, work-related variables and CSE.

A second hierarchical regression analysis was conducted with job satisfaction as the outcome. Demographics and work-related variables explained $7 \%$ of the variance: Respondents with higher income $(\beta=0.19, \mathrm{p}<0.01)$ and managerial position $(\beta=0.10, p<0.01)$ reported higher levels of job satisfaction. Furthermore, CSE accounted for an additional $12 \%$ of the variance in the second step $(\beta=0.37, p<0.01)$. Finally, in line with our hypothesis, DE proved a significant predictor, with two percent of explained variance in job satisfaction $(\beta=0.17$, $\mathrm{p}<0.01)$.

Relative income was introduced as the third outcome. Control variables accounted for $13 \%$ of the variance of this criterion. When combined with the objective measure of monthly income $(\beta=0.37, \mathrm{p}<0.01)$, respondents with a higher level of education perceived their income as lower in comparison to others $(\beta=-0.08, p<0.01)$. With regard to steps 2 and 3 , CSE explained one percent of the variance $(\beta=0.10, p<0.01)$ and DE showed itself to be a non-significant predictor of this criterion $(\beta=0.04$, n.s.).

Finally, we conducted a hierarchical regression analysis with perceived employability as the criterion. When introduced in the first step, gender, age, monthly income and managerial position accounted for a significant proportion of the variance of this outcome. Specifically, women $(\beta=-0.07, p<0.05)$ and older respondents $(\beta=-0.22, p<0.01)$ perceived themselves as less employable. The same can be stated for respondents with higher monthly income $(\beta=0.29, \mathrm{p}<0.01)$ and managerial position $(\beta=0.08, p<0.01)$. Furthermore, CSE added an extra nine percent of the explained variance in the second step $(\beta=0.32, p<0.01)$. When introduced in the third step, DE accounted for a significant proportion of the variance $\left(\Delta R^{2}=0.02, p<0.01\right)$, as hypothesized. 
DRUŠ. ISTRAŽ. ZAGREB GOD. 23 (2014), BR. 4, STR. 593-613

MASLIĆ SERŠIĆ, D. TOMAS, J.

THE ROLE OF..

\section{DISCUSSION}

Taken together, the results of hierarchical regression show that $\mathrm{DE}$ accounts for additional variance of subjective career success, job satisfaction and perceived employability after controlling for demographics, work-related variables and CSE, supporting the hypothesis of the incremental validity of this measure.

The present study deals with individual characteristics that could serve as personal resources for attaining a successful career in a modern 'ever-changing' work context. These characteristics should predict positive work outcomes, beside traditional predictors of work performance based on job analysis. As Harms and Brummel (2013) recently stated, with persistently high unemployment rates across Europe and the United States, "...it is clear that we need not only an understanding of what makes people successful in the jobs that they have but also an understanding of how to get them into the workforce and keep them there" (p. 20). The CSES is a well-established measure developed for this purpose, indicated by self-esteem, locus of control, generalized self-efficacy and low neuroticism (Judge et al., 2003). Similarly, the concept of DE has been proposed more recently with the primary goal of defining individual differences which predict employees' reactions to organizational change. While the concept of CSE is based on previously well-known concepts of personality traits and represents their brief composite measure, DE arises from another tradition. According to the model of DE (Fugate \& Kinicki, 2008), five individual characteristics - openness to changes at work, work and career resilience, work and career proactivity, career motivation and work identity - were chosen to represent an active work orientation and go beyond known concepts of personality traits.

Although Fugate and Kinicki (2008) proposed an elaborated and coherent model of $\mathrm{DE}$, these dimensions were not tested in different economic and cultural settings. In this regard, the Croatian context is characterized by several specificities. For example, while increased unemployment levels and intensified job insecurity are global phenomena, Croatian society is especially vulnerable in this regard. The labour market is not as dynamic as in other EU countries, and job-search intensity is a weak, or even not significant, predictor of re-employment after job loss (Šverko et al., 2008).

Moreover, it should be noted that there is still no general agreement on the first-order dimensions that should define DE. For example, McArdle, Waters, Briscoue, \& Douglas (2007) specified the idea of DE through a broader set of individual characteristics than Fugate and Kinicki (2008). On the basis of 
DRUŠ. ISTRAŽ. ZAGREB GOD. 23 (2014), BR. 4 STR. 593-613

MASLIĆ SERŠIĆ, D., TOMAS, J.: THE ROLE OF.. the psycho-social conceptualization of employability in Fugate et al. (2004), these authors defined DE through six individual characteristics: proactive personality, boundaryless mindset, career self-efficacy, identity awareness, networking and social support. The result of their study showed that DE was related to self-esteem and job search during unemployment, and also predicted re-employment success.

In the current study, DE was indicated by four first-order dimensions: work self-efficacy, work proactivity, work engagement and social capital. The stated individual characteristics defined a second-order factor - DE in Croatian society. Drawing on a confirmatory approach, we proved the discriminant validity of the two hypothesized measures - the CSES and the measure of DE - as well as their content validity. CSES and the DE measure showed acceptable scale validity, with a correlation between the two latent dimensions of 0.50 .

Two first-order individual characteristics that indicate DE in Croatian society - work proactivity and work engagement - are parallel to those proposed by Fugate and Kinicki (2008). While work proactivity corresponds to the dimension of work and career proactivity, work engagement can be interpreted as a combination of the career-motivation and work-identity dimensions of Fugate \& Kinicki's model (2008). Employees who have high levels of engagement are involved in their work and motivated in achieving their goals, and they define themselves through the work they do. Furthermore, the dimension of work proactivity is similar to the traits that predict employability orientation, the concept developed in the tradition of competence-based definitions of employability (Van Dam, 2004; Van der Heijde \& Van der Heijden, 2006). The other two dimensions - work self-efficacy and social capital - are distinct but familiar from the literature on unemployment as resources of employability at the individual level. As an indicator of self-rated ability to cope successfully with job demands (e.g. "I am capable of solving most of the problems at work"; "I complete my tasks successfully"), the dimension of work self-efficacy can be understood as an attitude-based measure of one's competence of occupational expertise, the first dimension of the competence-based model of employability as defined by Van der Heijde and Van der Heijden (2006).

According to De Battisti, Gilardi, Riccò, Siletti, \& Solari (2011) DE is indicated by social capital, proactivity and self-efficacy. These authors found the following characteristics essential for managing job change: (1) social capital identifies resources that people derive from their social networks; (2) proactivity in work and career reflects the tendency of people to gather information that may affect their professional de- 
DRUŠ. ISTRAŽ. ZAGREB GOD. 23 (2014), BR. 4, STR. 593-613

MASLIĆ SERŠIĆ, D. TOMAS, J.

THE ROLE OF. velopment opportunities, both inside and outside their organization; (3) self-efficacy in managing job changes refers to the individual's belief in being able to face job changes, and it is an aspect of openness to changes at work. Similarly, in our model, openness to change did not arise as a distinct dimension. We see this dimension as crucial for employability, but as a synonym for the disposition of employability rather than a first-order factor.

Hierarchical linear regression analyses, conducted for four different criteria, gave limited support to the incremental validity of the model of DE in predicting positive work outcomes. The regression model consisting of control variables (gender, age, education, monthly income, organizational tenure and managerial position), CSE and DE explained the highest proportion (46\%) of individual differences in perceived career success, followed by $26 \%$ in perceived employability, $21 \%$ in job satisfaction, and finally $13 \%$ in perceived relative income. The scales of CSE and DE had a significant impact in predicting perceived career success (CSE adding $16 \%$, and DE five percent of the explained variance), job satisfaction (CSE $12 \%$ and DE two percent) and perceived employability (CSE nine percent and DE two percent). CSE added to the prediction of individual differences in perceived relative income, but DE did not serve as an independent predictor of this criterion when entered in the last step of the analysis. Our results supported the claim that DE, as a broad trait, predicts career success in general. When it came to perceived employability, our assumption was based on a model proposed by Vanhercke, De Cuyper, Peeters, and De Witte (2014). According to these authors, the individual characteristics from the dispositional approach are conceived as input to employability, whereas perceived employability is seen as the output. In other words, positive work-related dispositions should predict one's perception of how easy it is to find new employment. The results showed that DE and CSE had independent and significant contributions in predicting individual differences in this criterion, indicating equal importance of both disposition-based approaches. In addition, bivariate correlations between CSE and DE with perceived employability were of similar, medium, effect size (amounting to 0.41 and 0.31 , respectively). However, it should be noted that, although significant, DE was a weak predictor of the perception of one's employability, a unique criterion due to its relevance to the concept of DE (see De Battisi et al., 2011). Age (that is, younger), gender (that is, male), monthly income and managerial position explained the highest proportion of the variance across almost all criteria. These variables can be described as human-capital measures, i.e., objective indicators of employability (Defillippi \& Arthur, 1994). 

GOD. 23 (2014), BR. 4 STR. 593-613

MASLIĆ SERŠIĆ, D., TOMAS, J.:

THE ROLE OF..
DRUŠ. ISTRAŽ. ZAGREB

The results of our study have several practical implications. In this regard, conceptualizations of employability through individual differences that are of a psycho-social nature could bring an additional perspective to dealing with employability on individual and group levels. How to develop and support individual characteristics which predict employability - this arises as the key issue. From an intra-organizational perspective, we see HRM strategies that enhance work autonomy, provide clear feedback to employees and support intra-organizational promotion and mobility as important for such a goal. In general, interventions with unemployed people that enhance proactive job search and networking could directly improve DE, as well as vocational schooling that supports proactive career planning and work and career self-efficacy.

To conclude, our four-dimensional model of DE showed construct validity, but its incremental validity is rather limited. Although it added to the prediction of perceived career success, job satisfaction and perceived employability above CSE, the amounts of added variance were rather small, especially regarding perceived employability. These results, as well as the limitations of the present methodology, stress the need for future research in the area. The results were obtained with a convenience sample, consisting of respondents from various organizations, but with unbalanced proportions of measured demographic and work characteristics. Furthermore, future research should test the incremental validity of the model of employability in the prediction of job search and well-being in a situation of organizational restructuring and unemployment, as well as in the prediction of career mobility and re-employment success after job loss (see also Van der Heijde, 2014).

\section{REFERENCES}

Arbuckle, J. L. (2012). AMOS 21.0 user's guide. Chicago, IL: SmallWaters Corporation.

Bentler, P. M. (1990). Comparative fit indexes in structural equation models. Psychological Bulletin, 107(2), 238-246. doi:10.1037/0033-2909. 107.2.238

Bentler, P. M., \& Bonnett, D. (1980). Significance tests and goodness of fit in the analysis of covariance structures. Psychological Bulletin, 88(3), 588-606. doi:10.1037//0033-2909.88.3.588

Berntson, E., \& Marklund, S. (2007). The relationship between employability and subsequent health. Work E Stress, 21(3), 279-292. doi:10.1080/02678370701659215 employability: Human capital or labour market opportunities? Economic and Industrial Democracy, 27(2), 223-244. doi:10.1177/0143831X 06063098
Berntson, E., Sverke, M., \& Marklund, S. (2006). Predicting perceived 
DRUŠ. ISTRAŽ. ZAGREB GOD. 23 (2014), BR. 4, STR. 593-613

MASLIĆ SERŠIĆ, D. TOMAS, J.:

THE ROLE OF.
Bono, J. E., \& Judge, T. A. (2003). Core self-evaluations: A review of the trait and its role in job satisfaction and job performance. European Journal of Personality, 17(1), 5-18. doi:10.1002/per.481

Briscoe, J. P., Hall, D. T., \& Demuth, R. L. F. (2006). Protean and boundaryless careers: An empirical exploration. Journal of Vocational Behavior, 69(1): 30-47. doi:10.1016/j.jvb.2005.09.003

Brown, T. A. (2006). Confirmatory factor analysis for applied research. New York: The Guilford Press.

Chang, C. H., Ferris, D. L., Johnson, R. E., Rosen, C. C., \& Tan, J. A. (2012). Core self-evaluations: A review and evaluation of the literature. Journal of Management, 38(1), 81-128. doi:10.1177/0149206311419661

De Battisti, F., Gilardi, S., Riccò, R., Siletti, E., \& Solari, L. (2011). Employability and involuntary occupational transitions management: An explorative research with workers on unemployment benefit. Departmental Working Papers 2011-41, Department of Economics, Management and Quantitative Methods at Università degli Studi di Milano. Available at http://wp.demm.unimi.it/tl_files/wp/2011/DEMM-2011_ 041wp.pdf

De Cuyper, N., Bernhard-Oettel, C., Berntson, E., De Witte, H., \& Alarco, B. (2008). Employability and employees' well-being: Mediation by job insecurity. Journal of Applied Psychology: An International Review, 57(3), 488-509. doi:10.1111/j.1464-0597.2008.00332.x

Defillippi, R., \& Arthur, M. (1994). The boundaryless career: A competency-based perspective. Journal of Organizational Behavior, 15(4), 307-324. doi:10.1002/job.4030150403

De Witte, H. (2000). Arbeidsethos en jobonzekerheid: Meting en gevolgen voor welzijn, tevredenheid en inzet op het werk [Work ethic and job insecurity: Measurement and consequences for well-being, satisfaction and productivity]. In R. Bouwen, K. De Witte, H. De Witte, \& T. Taillieu (Eds.), Van groep naar gemeenschap [From group to community]. Liber Amicorum Prof. Dr. Leo Lagrou (pp. 325-350). Leuven: Garant.

Dujšin, U. (1999). Nezaposlenost i politika zapošljavanja u zemljama u tranziciji: Hrvatska (Unemployment and employment policy in the transition countries: Croatia). Ekonomska istraživanja, 2(1-2), 1-19. DZS - Croatian Bureau of Statistics (2013). [http://www.dzs.hr/default e.htm]

Erez, A., \& Judge, T. A. (2001). Relationship of core self-evaluations to goal setting, motivation, and performance. Journal of Applied Psycho$\log y, 86(6), 1270-1279$. doi:10.1037/0021-9010.86.6.1270

EUROSTAT (2012). [http://epp.eurostat.ec.europa.eu/statistics_explained/ index.php/Unemployment_statistics]

Forrier, A., \& Sels, L. (2003). The concept employability: A complex mosaic. International Journal of Human Resources Development and Management, 3(2), 102-124. doi:10.1504/IJHRDM.2003.002414

Fugate, M., \& Kinicki, A. M. (2008). A dispositional approach to employability: Development of a measure and test of implications for employee reactions to organizational change. Journal of Occupational and Organizational Psychology, 81(3), 503-527. doi:10.1348/096 317907X241579 
DRUŠ. ISTRAŽ. ZAGREB GOD. 23 (2014), BR. 4, STR. 593-613

MASLIĆ SERŠIĆ, D., TOMAS, J.: THE ROLE OF.
Fugate, M., Kinicki, A. J., \& Ashforth, B. E. (2004). Employability: A psycho-social construct, its dimensions, and applications. Journal of Vocational Behaviour, 65(1), 14-38. doi:10.1016/j.jvb.2003.10.005

Greenhaus, J. H., Parasuraman, S., \& Wormley, W. M. (1990). Effects of race on organizational experiences, job performance evaluations, and career outcomes. Academy of Management Journal, 33(1), 64-86. doi: $10.2307 / 256352$

Hall, D. T. (2004). The protean career: A quarter-century journey. Journal of Vocational Behavior, 65(1), 1-13. doi:10.1016/j.jvb.2003.10.006

Harms, P. D., \& Brummel, B. J. (2013). The importance of developing employability. Industrial and Organizational Psychology, 6(1), 20-24. doi:10. 1111/iops.12003

Hillage, J., \& Pollard, E. (1998). Employability: Developing a framework for policy analysis. Research Brief 85. London: DFEE.

Hu, L., \& Bentler, P. M. (1999). Cutoff criteria for fit indexes in covariance structure analysis: Conventional criteria versus new alternatives. Structural Equation Modeling, 6(1), 1-55. doi:10.1080/10705519909540118 Judge, T. A., Bono, J. E., Erez, A., \& Locke, E. A. (2005). Core self-evaluations and job and life satisfaction: The role of self-concordance and goal attainment. Journal of Applied Psychology, 90(2), 257-268. doi:10.1037/0021-9010.90.2.257

Judge, T. A., Erez, A., Bono, J. E., \& Thoresen, C. J. (2003). The core self-evaluations scale: Development of a measure. Personnel Psychology, 56(2), 303-331. doi:10.1111/j.1744-6570.2003.tb00152.x

Judge, T. A., \& Hurst, C. (2008). How the rich (and happy) get richer (and happier): Relationship of core self-evaluations to trajectories in attaining work success. Journal of Applied Psychology, 93(4), 849-863. doi:10.1037/0021-9010.93.4.849

Judge, T. A., Locke, E. A., \& Durham, C. C. (1997). The dispositional causes of job satisfaction: A core evaluations approach. Research in Organizational Behavior, 19, 151-188.

Judge, T. A., \& Kammeyer-Mueller, J. D. (2011). Implications of core self-evaluations for a changing organizational context. Human Resource Management Review, 21(4), 331-341. doi:10.1016/j.hrmr.2010.10.003

Judge, T. A., Locke, E. A., Durham, C. C., \& Kluger, A. N. (1998). Dispositional effects on job and life satisfaction: The role of core evaluations. Journal of Applied Psychology, 83(1), 17-34. doi:10.1037/00219010.83.1.17

Landis, R. S., Beal, D. S., \& Tesluk, P. E. (2000). A comparison of approaches to forming composite measures in structural equation models. Organizational Research Methods, 3(2), 186-207. doi:10.1177/ 109442810032003

Lazarus, R. S., \& Folkman, S. (1984). Stress, appraisal and coping. New York: Springer Publishing Company.

Maslić Seršić, D., \& Šavor, M. (2012). Who will beat the crisis? Searching for factors that define successful coping with job loss among working people in Croatia. Problems of Psychology in the 21st Century, 2, 39-53. Available at http://www.scientiasocialis.lt/ppc/files/pdf/Sersic Vol.2.pdf 
DRUŠ. ISTRAŽ. ZAGREB GOD. 23 (2014), BR. 4, STR. 593-613

MASLIĆ SERŠIĆ, D. TOMAS, J.: THE ROLE OF.
Maslić Seršić, D., \& Šverko, B. (2000). Croatian workers in the period of transition: A five year follow-up of job-related attitudes. Social Science Information, 39(2), 363-376. doi:10.1177/053901800039002012

Maslić Seršić, D., Šverko, B., \& Galić, Z. (2005). Radne vrijednosti i stavovi prema poslu u Hrvatskoj: što se promijenilo u odnosu na devedesete? (Work values and job attitudes in Croatian employees: What has been changed after the 1990's?). Društvena istraživanja, 14(6), 1039-1054. Available at http://hrcak.srce.hr/18093

McArdle, S., Waters, L., Briscoue, J. P., \& Douglas, T. H. (2007). Employability during unemployment: Adaptability, career identity and human and social capital. Journal of Vocational Behavior, 71(2), 247-264. doi:10.1016/j.jvb.2007.06.003

Mischel, W. (1977). The interaction of the person and the situation. In D. Magnusson, \& N. S. Endler (Eds.), Personality at the crossroads: Current issues in interactional psychology (pp. 333-352). Hillsdale, NJ: Erlbaum.

Rode, J. C., Judge, T. A., \& Sun, J. (2012). Incremental validity of core self-evaluations in the presence of other self-concept traits: An investigation of applied psychology criteria in the United States and China. Journal of Leadership and Organizational Studies, 19(3), 326-340. doi:10.1177/1548051812442964

Sanders, J., \& De Grip, A. (2004). Training, task flexibility and low-skilled workers' employability. International Journal of Manpower, 25(1), 73-89. doi:10.1108/01437720410525009

Silla, I., De Cuyper, N., Gracia, F. J., Peiro, J. M., \& De Witte, H. (2009). Job insecurity and well-being: Moderation by employability. Journal of Happiness Studies, 10(6), 739-751. doi:10.1007/s10902-008-9119-0

Šverko, B., Galić, Z., Maslić Seršić, D., \& Galešić, M. (2008). Unemployed people in search of a job: Reconsidering the role of search behavior? Journal of Vocational Behavior, 72(3), 415-428. doi:10.1016/ j.jvb.2007.11.006

Taylor, S. E., \& Stanton, A. L. (2007). Coping resources, coping processes, and mental health. Annual Review of Clinical Psychology, 3(1), 377-401. doi:10.1146/annurev.clinpsy.3.022806.091520

Valverde, M., Tregaskis, O., \& Brewster, C. (2000). Labor flexibility and firm performance. International Advances in Economic Research, 6(4), 649-661. doi:10.1007/bf02295375

Vanhercke, D., De Cuyper, N., Peeters, E., \& De Witte, H. (2014). Defining perceived employability: A psychological approach. Personnel Review, 43(4), 592-605. doi:10.1108/PR-07-2012-0110

Van Dam, K. (2004). Antecedents and consequences of employability orientation. European Journal of Work and Organizational Psychology, 13(1), 29-51. doi:10.1080/13594320344000237

Van der Heijde, C. M. (2014). Employability and self-regulation in contemporary careers. In M. Coetzee (Ed.), Psycho-social career meta-capacities: Dynamics of contemporary career development (pp. 7-18). Dordrecht, The Netherlands: Springer International. doi:10.1007/ 978-3-319-00645-1_1

Van der Heijde, C. M., \& Van Der Heijden, B. (2006). A competence- 
DRUŠ. ISTRAŽ. ZAGREB GOD. 23 (2014), BR. 4, STR. 593-613

MASLIĆ SERŠIĆ, D. TOMAS, J.:

THE ROLE OF. of employability. Human Resource Management, 45(3), 449-476. doi:10. 1002/hrm.20119

Weinert, P. (2001). Introduction. In P. Weinert, M. Baukens, P. Bollérot, M. Pineschi-Gapènne, \& U. Walwei (Eds.), Employability: From theory to practice. New Brunswick (NJ): Transaction Publishers.

Worth, S. (2002). Education and employability: School leavers' attitudes to the prospect of non-standard work. Journal of Education and Work, 15(2), 163-179. doi:10.1080/13639080220137825

\section{Uloga dispozicijske zapošljivosti u predviđanju individualnih razlika u karijernom uspjehu}

Darja MASLIĆ SERŠIĆ, Jasmina TOMAS Filozofski fakultet, Zagreb

Ciljevi ovog istraživanja bili su: (1) revidirati model dispozicijske zapošljivosti Fugatea i Kinickija (2008) u hrvatskom ekonomskom kontekstu i (2) validirati novu Skalu dispozicijske zapošljivosti testirajući njezinu diskriminantnu i inkrementalnu valjanost $u$ odnosu na temeljne samoevaluacije. Hrvatska verzija Skale dispozicijske zapošljivosti konstruirana je na temelju kvalitativne studije i primijenjena na heterogenom uzorku od 966 zaposlenika. Osim navedenog, izmjerili smo temeljne samoevaluacije kao i četiri kriterijske varijable: subjektivni karijerni uspjeh, opće zadovoljstvo poslom, relativni prihod i percipiranu zapošljivost. Konfirmatorna faktorska analiza provedena je kako bi se ispitalo procjenjuju li mjere dispozicijske zapošljivosti i temeljnih samoevaluacija dvije različite dimenzije. Rezultati su u skladu s hipotezom o diskriminantnoj valjanosti ovih konstrukata. Nadalje, rezultati hijerarhijskih regresijskih analiza pokazali su da je dispozicijska zapošljivost objasnila dodatni udio u varijanci subjektivnoga karijernog uspjeha, zadovoljstva poslom i percipirane zapošlijvosti povrh kontrolnih varijabli i temelinih samoevaluacija. Ovi rezultati upućuju na karakteristike koje ljude čine zapošljivima u različitom ekonomskom kontekstu te pružaju empirijsku podršku valjanosti nove Skale dispozicijske zapošljivosti. Na kraju razmatramo ograničenja, implikacije i prijedloge za buduća istraživanja.

Ključne riječi: dispozicijska zapošljivost, temeljne samoevaluacije, karijerni uspjeh, diskriminantna valjanost, inkrementalna valjanost 